\title{
Chieftaincy Institutions among Yoruba Muslims in Nigeria: Between The Present And Past
}

\author{
Kamal-deen Olawale Sulaiman (Ph. D)*
}

\begin{abstract}
This paper intends to analyse the contemporary issues and challenges of chieftaincy Institutions among Yoruba Muslims in Nigeria. It delves in to the origins of Islamic chieftaincy institutions, the roles and functions of Islamic Chieftaincy title holders. The methodology employed was based on information and analysis of the data from written sources. The paper reveals that, the need to encourage believers in the propagation of Islam is a major reason for the multiplicity of chieftaincy titles. The paper recommended that for Islamic chieftaincy titles to be meaningful, preference should be given to Muslims who have the fear of Allah. While it concluded that in the early history merit and not mediocrity was the major consideration in the award of chieftaincy titles. The current trend therefore requires urgent review.
\end{abstract}

Key Words: chieftain, institution, contemporary, challenge, issue, conferment

\section{Introduction}

One of the many cultural concepts the Yoruba hold in high esteem is the chieftaincy title, because of its important value and role in the society. The Yoruba Muslims in Nigeria also admire the chieftaincy institution and the award of chieftaincy titles to their wards. This distinguishes the individual who earns it a place of respect and honour in the society and mosque. Another reason is that, Yoruba Muslims dissuaded themselves from seeking recognition from Traditional Kings (Obas) who are involved in some rituals and sacrifices. This was to help them maintain the injunctions of their faith as prescribed in the

\footnotetext{
${ }^{*}$ Lecturer, Department of Islamic Studis, College of Education Ikere Ekiti, Nigeria
} 
holy Qur'an and the Hadith of Prophet Muhammad. Though, in recent times, the chieftaincy titles have been used as a source of encouragement to them in the Muslim community. Islamic chieftaincy titles are also awarded to faithful members of the community who had contributed to the development of the mosque or help in the propagation of Islam in general.

However, Islamic chieftaincy title holders among the Yoruba perform unique roles within the Muslim community. Their roles go beyond the building of Mosques and facilitating the establishment of Arabic and Islamic School, they also contributed to improving the welfare of the Muslim community. During the Month of Ramadan fasting, they provide foods and drinks for poor members of the Muslim community essentially, they help in the propagation of Islam through spending of their money, energy and time for the cause of Islam. It is expected that such chieftaincy title holders will be responsible for seeing to the welfare of indigent members of the Muslim community within the town. Significantly, it is through these activities that people are appointed into various Islamic chieftaincy title positions among Yoruba Muslims.

In addition, if there is any form of cheating, maltreatment or molestation against Muslims, the Islamic chieftaincy title holders usually intervene in such matters to ensure fair treatment of the affected Muslims. An example can be seen in a situation where female secondary school Muslim students were agitating for the use of Hijab in schools. It was the intervention of the Islamic chieftaincy title holders that facilitated its acceptance in Oyo state.

Another important point to note is that they usually assist in settling disputes among members of the Muslim community. In recent times, Islamic chieftaincy title holders were the ones who usually ratify the persons to be appointed as Chief Imam in Yoruba towns. This duty became necessary for the Islamic chieftaincy title holder in Yoruba land because of the persistent conflicts that arise among the Ulama (Muslim scholars) on who should succeed to the position of Chief Imam.

\section{The Yorubas}

The Yoruba are one of the largest African ethnic groups in south of the Sahara desert ${ }^{1}$. They are, in fact, not a single group, rather a collection of diverse people bound together by a common language, history, and culture. Within Nigeria, the Yoruba dominate the western part of the 
country. Yoruba mythology holds that all Yoruba people descended from a hero called Odua or Oduduwa ${ }^{2}$. Today there are over fifty individuals who claim kingship as descendants of Odua. The Yoruba homeland is located in West Africa. It stretches from a savanna (grassland) region in the north to a region of tropical rain forests in the south ${ }^{3}$. Most Yoruba live in Nigeria. However there are also some scattered groups in Benin and Togo both countries are located to the west of Nigeria ${ }^{4}$. Yoruba Language has many dialects, but its speakers can all understand each other. As many as 20 percent of the Yoruba still practice the traditional religions of their ancestors 5 . The Yorubas who practice other religions are divided evenly between Muslims and Christians.

\section{What is Chieftaincy}

The term Chieftaincy could literally be translated to mean "the position of chieftain"6 while technical is used to describe the leader or head of a group, especially of a clan or tribe ${ }^{7}$. It could further be referred to as a chief or leader, especially of a clan or tribe ${ }^{8}$. Therefore Chieftaincy institution is a common phenomenon with states, empire, countries and other similar entities which make the institution a universal concept with a long history. It is also to create a leader-subject relationship, a social contract with a concerted motive the the leader would always protect and defend his or her subjects in time of war.

\section{The Origin of Chieftaincy Institutions in Islam}

Islam has much to say on the chieftaincy institution during the preIslamic and post- Islamic period of Arabian people. Though there was no established political authority among the Arabs, there were several clans which formed a tribe. Each tribe was headed by a democratically appointed "Shaykh" who would administer the public affairs of the members of his tribe. Those Shaykhs were democratically appointed, through the process of consultation and mutual deliberation among the council of Chiefs called "Ahl al-Ikhtiyar". Ahl al-Ikhtiyah were the people in the Arabian community, old and matured enough to have the proper choice of decision. This council of Ahl al-Ikhtiyar consisted of some chieftaincy title holders called Sayyid. Sayyid was neither a dictator nor a totalitarian, but a first among equals in the tribe which he represents. His authority rested on the consent of his represented tribe. This is the reason why Prophet Muhammad said: "Sayyid (Chief) of a tribe is nothing rather than a servant." 10

The highest chieftaincy title holders in the Arabian community were known as Mala' who were appointed among the nobles and prominent 
personalities. The decision of the council of Mala' affects the general people in the Arabian community ${ }^{11}$.

However, chieftaincy institutions among the Muslims are as old as Islam, because the origin of chieftaincy titles in Islam is traceable to Allah who besides making Prophets the leaders (Imams) of their communities also conferred on them some titles in recognition of their strong devotion to their missions. The Prophets conferred with titles were Ibrahim (Khalilullah - friend of Allah), Musa (Kalimullah - one to whom Allah spoke), Isa (Ruhullah - The spirit of Allah) and Muhammad (Habibullah - Beloved friend of Allah), Nabbiyyi-Allah and Rasul-Allah (prophet and messenger of Allah). Among women honoured by Allah were Asiyah, the wife of Pharaoh (the confidant of Allah) and Maryam (As-Siddiqah - A woman of Truth) ${ }^{12}$

During the lifetime of the Prophet of Islam, the practice of conferment of Islamic chieftaincy titles became well entrenched. He conferred chieftaincy titles on people for their high sense of devotion to Allah, justice and fair-play, goodness to people and moderation in dealings, continence, self-sacrifice and contentment. The Prophet conferred the title of Muezzin (prayer caller) on Bilal Ibn Rabah while titles such as as-saddiq (the trustworthy), al-Faruq (The Just), Dhu-Nurayn possessor of double stars) and Asadullah (The Lion of Allah) were conferred on caliphs Abubakar, Umar, Uthman and Ali respectively ${ }^{13}$. After the demise of Prophet Muhammad (S.A.W) in 532 C.E different titles emerged, such as Khalifah, Amiru'l-Muminin, Sultan, Wazir, Qadi Imam, Amir (president), Wali (local governor), Amil (tax collector) and Muhtasib during the time of the four rightly guided successors (Khulafa'ur-Rashidn) to the Prophet Muhammad (S.A.W.) Khalifah and Amirul- mumin were the political heads of the Islamic nation. Wazir are the vizier or governor of an Islamic province under an Islamic nation, Qadi (Islamic Judge), was in charge of court administration or the dispensing of justice, while Imam was in charge of religious activities of people in the Islamic nation ${ }^{14}$.

Also, Muslim leaders were duly recognized in early Islam. The Imam who was the head of government and leader of Salat (the ritual prayer) also would settle the disputes among his followers ${ }_{15}$. Other officials included the Khatib who preached or delivered sermon (Khutba) during the Jumu'a (Friday) service: and the Qass (wa'iz) and Qari who were concerned with street story-telling. The Mu'adhdhin, who was approved by the Prophet Muhammad (PBUH) to Bilal, serving as the 
first Mu'adhdhin, was responsible for calling the faithful to prayer; that is to assemble the community for the obligatory prayers. Other officials included the Khuddam (servants) who were responsible for various obligations in the mosque. The Nazir or Wali also performed duties in mosques management, especially in the payment of wages to those appointed as well as the administration of the bayt al-mal (the mosque treasury) ${ }^{16}$.

Furthermore, Islam strongly supports the institution of chieftaincy among its members. For example, in Arabic, which is popularly regarded as the language of Islam, the word Amir is often used as an honorary title for military or political leaders who have distinguished themselves in their behavior and conduct within the community ${ }^{17}$.

Chieftaincy title in Islam is an important tradition of the Arab world where Islam began and spread to other parts of the world. The Chiefs in Saudi Arabia were respected individuals and leaders within the community. In the Islamic religion, these chiefs were mostly charged with the responsibility of carrying out religious functions and settling communal dispute ${ }^{18}$. In some cases, the title is just symbolic, it is a mere symbol of greeting during social interaction. In a typical Islamic society, people are not known by their names but rather by their titles. These titles, most time, are self-explanatory to describe the personality of the title holders ${ }^{19}$. For example, the titles that were given to the companion of Prophet Muhammad only testify to the behavior and character of the individuals having such titles. For instance, Umar-al faruq clearly means (Umar that separates the truth from falsehood) ${ }^{20}$.

Furthermore, chieftaincy titles among the Arab evoke deep reflection and are an extension of the Islamic culture ${ }^{21}$. Titles are usually conferred on people without any ceremony or fuss, or taking them through elaborate feasting and entertainment as it is among the Yoruba people. Also, during the dynasty and caliphate periods, titles such as Caliph, Imam, Wazir, Qadi, Amil were prominent, ${ }^{22}$ in the northern part of Nigeria. With the establishment of Sokoto Caliphate in 1809, titles like Sultan, Amir, Imam, Qadi, Mu'adhdhin, Wali, were used as against the traditional Habe rulers' titles ${ }^{23}$.

\section{The Evolution of Islamic Chieftaincy Titles among the Yoruba}

Among the Yoruba Muslims in Nigeria, the practice of conferment of Islamic chieftaincy titles by the league of Imams and Alfas in southern Nigeria started in the $19^{\text {th }}$ century and continues till date with some 
peculiarities $^{24}$. Islamic titles are regarded among the people as social and religious honors within the community ${ }^{25}$. In other words, they are regarded as people -oriented and not service-oriented as is the case with the government structure ${ }^{26}$. Thus, it is believed among the people that the conferment of Islamic chieftaincy titles is a practice based on Yoruba culture and the Islamic religion ${ }^{27}$. For example, the Imam is considered in Islam as the religious leader of Muslims and the political head of the Muslim community whose instruction must be obeyed at all times based on the dictates of the Qur an and prophetic tradition ${ }^{28}$. $\mathrm{He}$ is expected to be a person knowledgeable in Islamic doctrine and practice; pious, and of good character.

The initial conception of award of titles to Muslims was for administrative purposes and for the expansion of Muslim activities, especially among the Yoruba Muslims in Nigeria ${ }^{29}$. First was the Imam Ratibi (Quarter Imam). With the rise in the number of Ratibi mosques, each under the leadership of an Imam Ratibi, began the problem of their place and role in the administrative hierarchy of the towns' entire Muslim community. In addition, there were more local scholars who were not necessarily Imam Ratibi but who, because of their knowledge and prestige, had to be brought into the administrative system.

Consequently, there emerged titles such as Naibul Imam, Olori Omokewu or Olori Alfaa (Head of Arabic scholars). There were also titles such as Ajanasi (preaching interpreter). It was the community that chose the Onitafsiru while scholars themselves selected the Olori Omokewu who was the spokesman of scholars and maintained liaison with the community.

These efforts were useful in integrating the rising school of learned men into the administrative structure of the community. But the posts were few and many scholars had to remain unattached to the administrative system. As for the Imams Ratibi, these were few leaders of their own quarters ${ }^{30}$, being so appointed by Muslims in that locality.

As for the entire community, more offices were created, amplifying or supplementing the existing ones. These titles were not necessarily created at the same time, but were introduced gradually as the community expanded. They were conferred on such deserving and influential Muslims within the community. A good example was the Naibul Imam (Deputy Imam). Then there came the Otun and Osi titles of the Balogun. New title such as Baba Adinni (Patron of Religion), 
which was conferred on active Muslims in advanced ages, Asipa Seriki (officer next in rank to the Balogun and leader of youths) and Sarumi (a rank below Seriki) came in largely in order to honour some influential Muslims and secure their support for the Muslim community.

In other words, the organization of the Muslim community was widened and modified to keep pace with the internal development within the community itself. Later on, in the life of Yoruba Muslims in Nigeria, the Muslim administrative system consisted of the Imam, Naibi, Onitafsiru, Baba Adinni, Balogun, Otun Balogun, Osi Balogun. (Sometimes called Eketa), Ekerin, Ajanasi, Seriki, Parakoyi, Sarumi, Asipa and Ladani. It was indeed a complex hierarchical structure that evolved but it was common. Some Muslim communities, such as those at Abeokuta and Oyo, evolved additional titles which were peculiar to them. For example at Abeokuta, there is also Oba Imale (King of the Muslims) existing side by side with the Imam.

In Badagry and Ekitiland, a Seriki Musulumi existed as an honorific, colorful title. In Lagos, there was the title of Bey which was conferred on shitta in 1894 and has since remained a perpetual but peculiar feature of the Lagos Muslim administrative structure.

The general pattern of the administrative system was, however, clear to a very large extent. All the Muslims chieftaincy title holders, together with the Imam Ratibi, the scholars and Giwas of the various Muslim associations, assisted the Imam and the other officers in the general administration of the affairs of the Muslim community.

For instance, they would look after the central mosque of each town, make necessary arrangements for festival prayers, welcome important visitors and settle disputes among Muslims. In the performance of these and other communal duties, it was not essential that Muslim title holders be present although they were normally contacted when deemed necessary. They were jointly responsible for the general welfare and development of the community as a whole.

Furthermore, it is important to mention that Islamic titles are not only found among the Yoruba-speaking people in Nigeria but also among the Hausa ethnic group in Nigeria where Islam is predominant. A comparable number of Islamic titles exist among the Hausa ethnic group in Nigeria. These include: Sarkin Hausawa (head of the Hausa community), Ciroma (crown prince), Galadima, Waziri (prime 
minister), Magajin Gari, Garikuwa, (supreme commander), to mention but a few. All these title holders contributed effectively in the running of the affairs of the Hausa communities found among Yoruba people in the Sabo areas of Yoruba land ${ }^{31}$.

At present, Islamic title abound in almost all the Yoruba towns where Muslims are found. They are found in the local mosques of quarters in villages as well as towns. Islamic titles are conferred on people with distinctive qualities among the Muslim community. They are people who are found worthy in character, are generous donors and philanthropists who help in the cause of propagating Islam through learning and building of mosques ${ }^{32}$. Islamic titles among Yoruba people are also used to celebrate important personalities that have contributed in one way or the other to the development of Islam in the town ${ }^{33}$. These people are most times very influential, wealthy and knowledgeable Muslims. These Islamic chieftaincy titles are also conferred on Muslims to discourage them from taking unIslamic chieftaincy titles, inculcate in their minds Islamic orientation and awareness and to maximize the use of their influence and financial buoyancy in the cause of Islam ${ }^{34}$. The system has aided the spread of Islam in Yorubaland. The chieftaincy title holders have been contributing their quotas immensely in the religious, educational, social, political and economic advancement of the Muslims and Islam in their areas through the use of their political and financial powers ${ }^{35}$.

\section{Contemporary Trends and Challenges}

Today, chieftaincy titleholders among Muslims are of different backgrounds, with varying motives and activities ${ }^{36}$. Whereas the intention of the early Muslims in conferring chieftaincy titles was to serve as an incentive, drive and encouragement, it is different nowadays due to the following reasons:

A. Political Consideration: Islamic Chieftaincy titles nowadays are being conferred based on political considerations and motives rather than motivation for the propagation of Islam. This trend was noticeable at the dawn of the Second Republic in 1979. The defunct Unity Party of Nigeria (UPN) and the National Party of Nigeria (NPN) began to use the Mosque and chieftaincy titles among Muslims to score political points. It was a period when a serving Muslim governor would attend church service with his cap removed in the typical Christian deference to Allah, or when a non-Muslim politician was allowed to enter the mosque with disdain for the ethics and teachings of Islam. Also, it is 
now common among the Yoruba Muslims when any Muslims assume a political post, the Muslims would confer on such people an Islamic chieftaincy title in order to extort money from them. They do not consider whether these people are knowledgeable or not.

The politicization of Muslim chieftaincy titles has gone to such an extent today that even non-Muslims are being awarded titles in order to curry their favour on political consideration. The result is that Muslims now have Muslim title holders who know next to nothing about Islam, including the observance of the five canonical prayers. Most of them that go on pilgrimage do so mainly for socialization and bearing of the title of Alhaji or Alhaja. Thus, little or no value is attached to Muslim titles from the current trend.

Recently, at a political gathering in a town in Yorubaland in Nigeria, a politician who was given a Muslims title could not recite Sural Fatiha (the first Chapter of the holy Qur'an) during the opening prayer. This is because he knew very little, if anything at all, about Islam. He was given the title as a result of his political profile.

B. Financial Inducement: Most Muslim chieftaincy titles now go to the highest bidder. Moneybags now have a free access to any religious title in their community as long as they can pay their way. This trend has turned the turbaning ceremony in mosques to a mere jamboree of sort. This is because there is absence of religious fervour in the conferment of such titles.

The rate of crime, fraud and high-profile corruption in Nigeria today, including the sharing of unspent budgetary allocations as Christmas gifts among Muslim public servants, is largely due to the thirst of many for the acquisition of titles using their financial muscle. The Imams do not bother much about ill-gotten wealth of would be title holders, even if they are drug pushers. And the society at large seems to be satisfied as long as money can exchange hands.

C. Tribal Affiliation: Unlike the early Muslims who considered titles as a weapon for unity, cohesion and strong social solidarity, the trend among Muslims today, especially in Yorubaland, is the promotion of tribal linage rather then merit. 


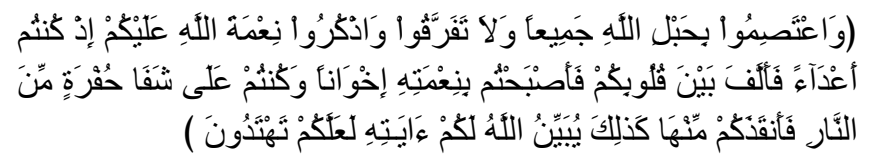

And hold fast, all of you together, to the Rope of Allah, and be not divided among yourselves, and remember Allah's favor on you, for you were enemies of one another but He joined your hearts together, so that, by His grace, you became brethren, and you were on the brink of a pit of Fire, and He saved you from it. Thus Allah makes His Ayat clear to you, that you may be guided. (Qur'an, 3: 103). The great Prophet while appointing Bilal as the first Muadh-dhin in Islam knew that he was non-Arab, a slave, and a man of low status. Yet Bilal occupied such a prominent position in the history of Islam without anybody caring about his poor background.

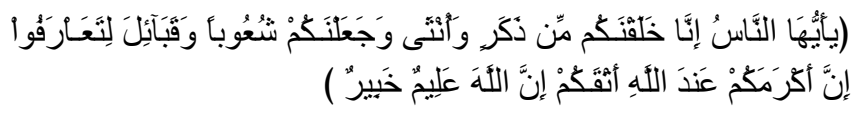

O mankind! We have created you from a male and a female, and made you into nations and tribes that you may know one another. Verily, the most honorable of you with Allah is that (believer) who has At-Taqwa. Verily, Allah is All-Knowing, All-Aware.

(Qur'an, 49: 13)

The current trend among Muslims portrays Islamic Chieftaincy title holders as tribal leaders who are out to serve and protect their kinsmen's interests alone, even within the Mosques. The question is that, when last was the cleaner in the mosque or the Mu'adh-dhin (Caller to Prayer) conferred with an Islamic Chieftaincy title?

D. Ego and selfish interests: A Muslim, by definition, is one who submits himself or herself to Allah alone in all affairs ${ }^{37}$. He does not seek for any worldly position and when called to service, must humble himself. This principle seems to have faded away among Muslims who nowadays seek Islamic titles only to satisfy their ego and selfish interests. The award of Islamic titles has assumed an unfortunate dimension. This is because the occupiers of these positions could be people of questionable characters in the society.

To many Muslim, one's image and honour can only be measured by the array of titles one can parade and in how many communities one 
has been so recognized. This trend is quite contrary to the aims of the early Muslims who conferred any honour or title on people for their role in the spread of Islam.

\section{Recommendations}

For Islamic chieftaincy titles to be meaningful, preference should be given to Muslims who are steadfast, loyal, committed to the cause of Islam and, above all, have the fear of Allah. The League of Imams and Alfas in Yorubaland in Nigeria should come up with a blueprint on the conditions and criteria for awarding of Islamic titles to any Muslim. It is recommended that at no point should financial inducement, tribal consideration and political affiliation be allowed to be determining as a factor for the conferment of Islamic chieftaincy titles. The paper equally recommends for conducting of interview to whoever is to be turbaned as an Islamic chieftaincy holder or given any position in the mosque. The idea that an Islamic chieftaincy title holder must emerge from a particular family, even where there are more brilliant scholars and dedicated person in town, should be discouraged.

The idea of awarding Islamic chieftaincy titles which started with the four rightly guided Caliphs of Prophet Muhammad was a milestone in the history of Islam. The positions were well deserved. In the history of Islam among the Yoruba, merit and not mediocrity was the major consideration in the award of Islamic chieftaincy titles to Muslims. The current trend therefore requires urgent review by the league of Imams and Alfas in southern Nigeria who are the competent authority to confer chieftaincy titles. As pointed out in this paper, Islamic chieftaincy titles among Muslims should be a motivation for greater dedication to service in the cause of Allah rather than for monetary gains and political patronage.

\section{Conclusion}

In conclusion, the paper reveals that, the origin of Islamic chieftaincy titles is traceable to Allah who besides making Prophets the leaders of their communities also conferred on them some chieftaincy titles in recognition of their strong devotion to their missions. It also identifies that chieftaincy title in early Islamic days was in line with what is operating among Yoruba Muslims. However, the modification and addition are due to cultural variations in terms of the number of those who are recognized with the various chieftaincy titles. Also, the need to encourage believers to aid the propagation of Islam is another reason for the multiplicity of chieftaincy titles among Yoruba 
Muslims. It also confirms that, Islamic chieftaincy title holders perform unique roles within the Muslim community. Islamic chieftaincy titles were also used to honor the efforts and contributions made by individual Muslims in major Yoruba cities who have distinguished themselves, particularly in such areas as building of mosques and Islamic institutions. The paper also asserts that, the issue of Islamic chieftaincy titles today is shrouded in politics, tribalism and nepotism which are all against Islamic teachings. Among the major motives are: political consideration, financial inducement and tribal affiliation.

\section{Notes and References}

1. KOSLOW, PHILIP (1996): Yorubaland: The Flowering of Genius. Kingdoms of Africa, New York: Chelsea House, Pp, 32-38 See also, Akinjogbin, I. A. and AYANDELE, E. A (1980): "Yorubaland Up to 1800" Ikimi, $O$ (ed) Groundwork of Nigerian History, Ibadan, Heinemann Educational Books (Nigeria) Pls, Pp, 22-29

2 BOLAJI, E. I (1962): Olodumare, God in Yoruba Belief, London, Longman, Pp, 50-56

3 ADENIRAN, A (1985) "The Yoruba Kingdom" in Falola T, and Adeniran A (eds) A New History of Nigeria for Colleges Book One, Ikeja, John West Publication Ltd, Pp, 3-8 See also, HETFIELD, JAMIE. (1996): The Yoruba of West Africa. New York: Rosen Publishing Group, Pp, 52-53

4 OJO, G. J.A (1966): Yoruba Culture: A Geographical Analysis, London, University Press, Pp, 80-82

5 FADIPE, N. A (1970): The Sociology of the Yoruba (Okedeji, F. O and OLADEJI, O. O Eds), Ibadan, Ibadan University Press, Pp, 30-34

6 The Free Dictionary http://www.thefreedictionary.com/Chieftaincy Retrieved on 20/10/2012

7 ONDO STATE OF NIGERIA (1992) Ondo- State Annual Digest, Stainless Publication Ltd, Abuja, Pp, 186 and 218-219

8 AKINGBEMI, G.B (2007) Ikale People and Culture, Third World Media Ltd, Lagos, P. 10 
Chieftaincy Institutions among Yoruba Muslims in Nigeria: Between The Present And Past

9 ABDUL, M. O.A (1988): The Classical Caliphate (Islamic Institution), Lagos Islamic Publication Bureau, p.117

10 Islamic Scholar Software. Sahih Muslim (Johannesburg, South Africa: Par Excellence Computers, Abu Hurairah, hadith no. 4542.

11 MARDINI, S (1986) "Fundamental Religious Political Concepts in the Source of Isla" In Hamdard Islamicus, Vol. ix, No. 4 Pakistan: Hamdard Publications, Pp, 9-12

12 ALIAGAN, Z.I. and ADEDIMEJI, M.A.( 2004): Stories from the Qur'an. Lagos: Fountain Media and Pioneer Printers, Pp, 12-18

13 KHAN, M.A. (1990): The Pious Caliphs. Britain: Dwan Press, p.15

14 ZIDAM, A. (1998): The Rightly Guided Caliphs, Egypt, Islamic Inc, Publishing, Pp, 10-15

15 PERDERSON, J (1990) "Masjid” Encyclopaedia of Islam. Leiden: E. J. Brill, Pp, 644-677

16 BALOGUN, I. A.B (1975): The Life and Works of Uthman Dan Fodio, Lagos, Islamic Publication Bureau, Pp, 26-28

17 AKEEM O.A (2010) "A Historical Analysis of Chieftaincy Titles in Islam among the Yoruba" in Chieftaincy Institution in Nigeria, Lagos, Centre for Black and African Art and Civilization (CBAAC), 50-53

18 IBN. KHALIDUN, (N.D) AL-Muqaddimah, Vol, 11, Cairo N.P, P, 32

19 ABDUL, M. O.A (1988): The Classical... Op. Cit, p.117

20 UBAH C.N (1987) "Islamic Culture and Nigeria Society" In E Ihekweazu (ed), Readings in African Humanities, Enugu, Pp, 17-20

21 ABUBAKAR .S. (1970) "The Emirate of Fombia, 1809-1903" An Unpublished Ph.D Thesis Submitted to the Department of History, Ahmadu Bello University, Zaria , Pp, 28-31

22 Watt Montgomery, M. (1968): Islamic Political Thought. Edinburgh: University Press See also,SHABAN, M.A. (1971): Islamic History: A New Interpretation. London: Cambridge University Press, pp. 152-153

23 LAST, M. (1967): The Sokoto Caliphate. London: Longmans, P. 50

24 AJETUNMOBI, M.O.A. (1988) "Shari'ah Legal Practice in Nigeria 1956-1983" Unpublished Ph.D. Thesis Submitted to the Department of 
Religions, University of Ilorin, p.42, See also, GBADAMOSI, T.G.O.( 1978): The Growth of Islam among the Yoruba 1841-1908. Ibadan: Longman, p.348.

25 VAUGHAN, O (2003) "Chieftaincy Politics and Communal Identity in Western Nigeria 1893-1951 “ In Journal of African History, P. 35

26 AJAYI, A. and EPIE, I. (1965): A Thousand Years of West African History. Ibadan, Ibadan University Press and Nelson, p.276

27 AKEEM O.A (2010) “A Historical Analysis of ... Op. Cit, 50-53

28 ABDULlAH U A, (2003) Chieftaincy and Security in Nigeria, Kano, Research and Documentation Directorate, P. 32

29 GBADAMOSI, T.G.O.( 1978): The Growth of Islam among the Yoruba 1841-1908. Ibadan: Longman, p.348.

30 DANOYE O, L (2002) "Roles of Traditional Rulers and Religious Rulers in Conflict Management" Al-Hadara, LASU Journal of Arabic and Islamic Studies, Vol, 5, June, Pp. 7-10

31 AKEEM O.A (2010) “A Historical Analysis of ... Op. Cit, 50-53

32 JAMIU, S.M (1992) "Islam Title Holders in Yourbaland" In Orita Ibadan Journal of Religion Studies, xxivii-21 June/December, Pp. 7-10

33 LATEJU F.T, (2010) "Chieftaincy in Islamic and its Religion-Cultural implication in Yorubaland" in Chieftaincy Institution in Nigeria, Lagos, Centre for Black and African Art and Civilization (CBAAC) Pp. 40-43

34 ADEKUNLE, B.M. (1997) "A Critical Analysis of the Origin, Development and Effects of Muslim Chieftaincy titles in Yorubaland: Ibadan as a case study" M.A. Thesis, Department of Religions, University of Ilorin, pp.27-32.

35 OLOYEDE, I. O. ( 1997) "The Council of Muslim Youth Organisation (COMYO) in Oyo State, Islamic Studies, Vol. 26, N.o.1 Islamabad: Islamic Research Institute, Pp. 17-19

36 OLADIMEJI, L.F (2010) "Modern Trends and Challenges of Chirftaincy Titles among Muslims in Southwest Nigeria" in Chieftaincy Institution in Nigeria, Lagos, Centre for Black and African Art and Civilization (CBAAC), Pp. 38-40

37 ABDUL, M. O.A (1988): The Classical... Op. Cit, p.117 